\title{
Peran Akar Kayu Bayur (Pterospermum sp.) terhadap Fermentasi Nira Aren (Arenga pinnata)
}

\section{The Role of Wood Root Bayur (Pterospermum sp.) toward Sugar Palm Nira Fermentation (Arenga pinnata).}

\author{
${ }^{1)}$ Siti Nurlina Mentari, ${ }^{2)}$ Muhammad Jasri Djangi, ${ }^{3)}$ Sudding \\ ${ }^{123)}$ Jurusan Kimia Fakultas Matematika dan Ilmu Pengetahuan Alam \\ Universitas Negeri Makassar, Jl. Dg Tata Raya Makassar, Makassar 90224 \\ Email : nurlinamentari@yahoo.co.id
}

\begin{abstract}
ABSTRAK
Penelitian ini bertujuan untuk mengetahui peran akar kayu bayur terhadap fermentasi nira aren dengan parameter pengukuran yaitu derajat keasaman $(\mathrm{pH})$ dan kadar alkohol. Peran akar kayu bayur (Pterospermum sp.) dapat dilihat dari nilai $\mathrm{pH}$ dan kadar alkohol hasil fermentasi nira aren tanpa penambahan akar kayu bayur dengan nira aren menggunakan akar kayu bayur selama proses fermentasi 72 jam. Hasil penelitian menunjukkan bahwa akar kayu bayur yang ditambahkan pada nira aren berfungsi sebagai pengawet tuak sehingga menyebabkan kadar alkohol hasil fermentasi nira aren bertahan lebih lama pada konsentrasi $4 \%$ selama 64 jam serta memperlambat fermentasi alkohol menjadi asam asetat.

Kata kunci : Nira aren (Arenga pinnta), Akar kayu bayur (Pterospermum sp), Fermentasi
\end{abstract}

\begin{abstract}
This research aimed to determine the role of wood root bayur toward the fermentation of sugarpalm nira with measuring parameters, i.e, the degree of acidity $(\mathrm{pH})$ and alcohol content. Role of wood root bayur (Pterospermum sp.) was observed from the $\mathrm{pH}$ value and the alcohol content of fermented sugarpalm nira without the addition of wood root bayur compared to the fermented sugarpalm nira using wood root bayur during the 72 hours of fermentation. The results showed that the wood root bayur added to the sugarpalm nira served as nira preservatives, causing the alcohol content of fermented sugarpalm nira last longer at the concentration of $4 \%$ for 64 hours and retarding the fermentation of alcohol into acetic acid.
\end{abstract}

Key words: Sugarpalm nira (Arenga pinnata), Wood root bayur (Pterospermum sp.), Fermentation 


\section{PENDAHULUAN}

Indonesia merupakan wilayah yang memiliki kekayaan alam melimpah. Berbagai jenis tumbuhan di Indonesia mempunyai banyak manfaat bagi kelangsungan hidup manusia. Salah satunya adalah tanaman aren (Arenga pinnata) yang termasuk dalam kelompok palmae.

Aren merupakan salah satu sumber bahan pangan yang hampir semua bagian dari pohonnya dapat dimanfaatkan dan memiliki nilai ekonomi mulai dari bagian-bagian fisik pohon maupun dari hasil-hasil produksinya. Ketersediaan sumber daya tersebut juga merata di seluruh Indonesia seperti Sulawesi Selatan yang memiliki potensi aren yang cukup besar. Hampir semua bagian fisik dan produksi dari tumbuhan tersebut dapat dimanfaatkan dan memiliki nilai ekonomi. Akan tetapi dalam pemanfaatan pohon aren oleh masyarakat, nira adalah yang paling banyak digunakan.

Nira adalah bahan yang mudah sekali mengalami kerusakan. Penyebab utama rusaknya nira adalah akibat adanya kontaminasi oleh mikroorganisme khususnya khamir dan bakteri. Jenis mikroorganisme tersebut adalah Saccharomyces sp. dan Acetobacter sp. (Lutony, 1993). Nira yang telah terkontaminasi oleh mikroorganisme, akan mengalami proses fermentasi atau perombakan terhadap senyawa-senyawa penyusunnya. Karena fermentasi tersebut maka sukrosa yang terdapat dalam nira akan berubah menjadi alkohol dan selanjutnya berubah menjadi asam cuka.
Secara tradisional, nira aren banyak dimanfaatkan oleh masyarakat di pedesaan menjadi minuman segar yang dapat meningkatkan energi atau tenaga dalam bekerja, dan dapat menghangatkan tubuh. Di kalangan masyarakat Sulawesi Selatan khususnya masyarakat Kabupaten Maros, nira aren juga difermentasi menjadi semacam minuman beralkohol yang disebut tuak.

Berdasarkan hasil wawancara yang dilakukan Penulis saat melakukan KKN PPM pada tahun 2014 dengan salah satu petani aren yang berada di Dusun Kappang, Desa Labuaja, Kecamatan Cenrana, Kabupaten Maros menyatakan bahwa tuak ini diperoleh dengan menambahkan akar kayu bayur (Pterospermum sp.) ke dalam penampungan nira. Akar kayu bayur (Pterospermum sp.) atau yang dikenal oleh masyarakat sekitar dengan sebutan akar kayu merah digunakan sebagai bahan pencampur nira aren. Beberapa masyarakat sekitar berpendapat bahwa penambahan akar kayu bayur bertujuan untuk mempercepat fermentasi dan meningkatkan kadar alkohol dalam tuak.

Bayur atau yang dalam bahasa daerah disebut Banyoro adalah tumbuhan khas dari Sulawesi yang merupakan salah satu tumbuhan yang mengandung senyawa fenolat. Telah dilakukan pula penelitian mengenai pemeriksaan farmakognostik tumbuhan ini dan penapisan komponen kimia secara kromatografi lapis tipis, dan dilaporkan bahwa pada daun, kulit 
batang, dan batang ditemukan adanya senyawa tannin, katekin, fenol dan steroid (Marzuki dkk, 2008).

Salah satu jenis kulit kayu yang juga digunakan dalam pencampuran nira aren adalah kulit bakau yang telah dikenal mampu meningkatkan kadar alkohol dan dapat pula menghambat pembentukan asam asetat. Firdaus (2003) dalam penelitiannya terhadap penambahan serbuk kulit batang Sonneratia sp. pada fermentasi nira aren terlihat bahwa alkohol yang diperoleh dari fermentasi tanpa penambahan serbuk kulit kayu Sonneratia sp. secara keseluruhan menurun dengan bertambahnya waktu fermentasi, sedangkan fermentasi dengan penambahan serbuk kulit kayu Sonneratia sp. terjadi peningkatan dari hari pertama sampai hari kelima, dan setelah itu turun perlahan-lahan. Penggunaan kulit bakau ini juga dapat menghambat (inhibitor) proses fermentasi lebih lanjut etanol menjadi asam asetat.

Berdasarkan uraian di atas, maka penulis tertarik untuk mengadakan penelitian mengenai peran akar kayu bayur terhadap fermentasi nira aren.

\section{METODE PENELITIAN}

\section{A. Alat dan Bahan}

Alat-alat yang digunakan dalam penelitian ini diantaranya termos, blender, jirgen 1 liter, alatalat analisis berupa gelas ukur $100 \mathrm{ml}$, gelas kimia $50 \mathrm{ml}$, botol-botol kaca, gunting, neraca analitik, batang pengaduk, spatula, termometer, $\mathrm{pH}$ meter, dan alkoholmeter.
Bahan utama yang digunakan adalah nira aren (Arenga pinnata), akar kayu bayur (Pterospermum sp.). Sedangkan bahan kimia yang digunakan yaitu alkohol $70 \%$, larutan buffer 7, larutan buffer 4 . aluminium foil, indikator universal, dan aquades.

B. Prosedur Kerja

1. Persiapan Bahan Baku dan Preparasi Sampel

a. Pengambilan Akar Kayu Bayur Akar kayu bayur (Pterospermum sp.) diambil dari daerah Dusun Kappang Desa Labuaja Kecamatan Cenrana, Kabupaten Maros, Sulawesi Selatan. Akar kayu bayur (Pterospermum sp.) dibuat serbuk dengan cara diblender.

b. Pengambilan Nira Aren

Nira aren segar diambil langsung dari petani di Wilayah Kecamatan Cenrana Kabupaten Maros Sulawesi Selatan. Nira Aren yang digunakan dalam penelitian ini yaitu nira aren murni tanpa penambahan apapun.

\section{Fermentasi}

Fermentasi dilakukan dengan cara nira aren sebanyak $100 \mathrm{ml}$ dimasukkan kedalam botol kaca, lalu ditambahkan serbuk akar kayu bayur sebanyak 1 gram. Fermentasi dilakukan selama 72 jam dan diukur $\mathrm{pH}$ dan kadar alkoholnya setiap 8 jam menggunakan $\mathrm{pH}$ meter dan alkoholmeter. 


\section{HASIL DAN PEMBAHASAN}

\section{A. Hasil Penelitian}

Adapun hasil pengukuran $\mathrm{pH}$ dan kadar alkohol yang diperoleh dalam penelitian ini dapat dilihat pada Tabel 1.

Tabel 1. Nilai pH dan Kadar Alkohol Hasil Fermentasi Nira Aren

\begin{tabular}{ccccc} 
No & $\begin{array}{c}\text { Waktu } \\
\text { Fermentasi } \\
(\text { Jam) }\end{array}$ & Nira Aren & $\begin{array}{c}\text { Nira Aren + } \\
\text { Akar Kayu } \\
\text { Bayur }\end{array}$ & $\begin{array}{c}\text { Kadar Alkohol } \\
\text { Nira Aren + } \\
\text { Akar Kayu } \\
\text { Bayur }\end{array}$ \\
\cline { 3 - 5 } & & 5,035 & 5,035 & 0 \\
\hline 1 & 0 & 4,067 & 4,460 & 2 \\
\hline 2 & 8 & 3,988 & 4,455 & 4 \\
\hline 3 & 16 & 3,971 & 4,451 & 4 \\
\hline 5 & 24 & 3,948 & 4,448 & 4 \\
\hline 6 & 32 & 3,920 & 4,446 & 4 \\
\hline 7 & 40 & 3,889 & 4,438 & 4 \\
\hline 8 & 48 & 3,878 & 4,426 & 4 \\
\hline 9 & 66 & 3,865 & 4,422 & 3 \\
\hline 10 & 72 & 3,851 & 4,404 & 4 \\
\hline
\end{tabular}

\section{B. Pembahasan}

\section{Fermentasi}

Gula pada nira aren cenderung mengalami fermentasi secara spontan menjadi alkohol yang diikuti dengan fermentasi asam. Nira aren mudah mengalami kerusakan karena dipengaruhi oleh kondisi lingkungan selama penyadapan. Fermentasi pada nira aren disebabkan oleh aktivitas enzim invertrase yang dihasilkan oleh mikroba yang mengkontaminasi nira (Hamzah dan Hasbullah, 1997). Mikroba tersebut antara lain Saccharomyces cerevisiae yang membantu proses hidrolisis sukrosa menjadi gula reduksi didalam nira (Goutara dan Wijandi, 1980).
Saccharomyces cereviceae menghasilkan enzim zimase dan invertase. Enzim zimase berfungsi sebagai biokatalis yang dapat mengubah glukosa dan fruktosa menjadi alkohol dan $\mathrm{CO}_{2}$, sedangkan enzim invertase berfungsi mengubah sukrosa menjadi gula invert (glukosa dan fruktosa) (Poedjiadi dan Titin, 2007).

Adapun reaksi perubahan sukrosa menjadi gula pereduksi dan asam pada nira aren yaitu: 


$$
\begin{aligned}
& \underset{\text { Sukrosa }}{\mathrm{C}_{12} \mathrm{H}_{22} \mathrm{O}_{11}}+\underset{\text { Air }}{\mathrm{H}_{2} \mathrm{O}} \stackrel{\text { enzim invertase }}{\longrightarrow} \underset{\text { Glukosa }}{\mathrm{C}_{6} \mathrm{H}_{12} \mathrm{O}_{6}}+\underset{\text { Fruktosa }}{\mathrm{C}_{6} \mathrm{H}_{12} \mathrm{O}_{6}} \\
& \mathrm{C}_{6} \mathrm{H}_{12} \mathrm{O}_{6} \stackrel{\text { ragi }}{\longrightarrow} 2 \mathrm{C}_{2} \mathrm{H}_{5} \mathrm{OH}+2 \mathrm{CO}_{2} \\
& \text { Glukosa Etil alkohol Karbon dioksida } \\
& \underset{\text { Etil alkohol }}{2 \mathrm{C}_{2} \mathrm{H}_{5} \mathrm{OH}}+\mathrm{O}_{2} \longrightarrow \underset{\text { Asam asetat }}{\mathrm{CH}_{3} \mathrm{COOH}}+\mathrm{H}_{2} \mathrm{O}
\end{aligned}
$$

\section{Nilai pH}

Berdasarkan hasil penelitian pada Tabel 1 dapat dilihat bahwa nilai $\mathrm{pH}$ hasil fermentasi nira aren tanpa penambahan akar kayu bayur lebih rendah dibandingkan nilai $\mathrm{pH}$ pada nira aren dengan penambahan akar kayu bayur. Tabel 1 menunjukkan bahwa yang memiliki perubahan nilai $\mathrm{pH}$ yang sangat signifikan selama proses fermentasi ditunjukkan pada nira aren tanpa penambahan akar kayu bayur. Sedangkan nilai $\mathrm{pH}$ hasil fermentasi nira aren dengan penambahan akar kayu bayur lebih konstan selama proses fermentasi 72 jam. Hal tersebut disebabkan karena penambahan akar kayu bayur mampu menghambat laju penurunan nilai $\mathrm{pH}$ yaitu menghambat reaksi pembentukan asam.
Perubahan nilai $\mathrm{pH}$ pada fermentasi dapat menyebabkan terjadinya proses denaturasi (proses yang menyebabkan gangguan terhadap aktivitas sel dan kemungkinan kematian sel) sehingga menurunkan aktivitas enzim. Pada $\mathrm{pH}$ dibawah 4 aktivitas enzim akan terhambat sehingga kemampuan mikroba untuk mengurai gula menjadi etanol semakin rendah (Putra dan Arman, 2009).

\section{Kadar Alkohol}

Perlakuan penambahan akar kayu bayur memberikan pengaruh yang nyata terhadap kadar alkohol hasil fermentasi nira aren. Berdasarkan hasil penelitian pada Tabel 1 menunjukkan bahwa kadar alkohol hasil fermentasi nira aren dengan penambahan akar kayu bayur konstan pada konsentrasi $4 \%$ selama proses fermentasi 64 jam. Sedangkan pada fermentasi 72 jam kadar alkohol hasil fermentasi nira aren turun menjadi $3 \%$.

Berdasarkan hasil penelitian menunjukkan bahwa penambahan akar kayu bayur berfungsi sebagai pengawet tuak agar tuak lebih tahan lama. Hal ini sangat berbeda dengan beberapa pendapat masyarakat di Dusun Kappang Desa Labuaja Kabupaten Maros yang menyatakan bahwa penambahan akar kayu bayur bertujuan untuk mempercepat fermentasi dan meningkatkan kadar alkohol dalam tuak.

Kemampuan mengawetkan disebabkan adanya senyawa tanin (Winarno, 1989) yang mampu mengendapkan protein dan mengikat ion logam yang menghambat aktivitas enzim mikroorganisme. Apabila tidak ada usaha pengawetan setelah nira mengalami pembentukan alkohol (tuak), fermentasi akan berlangsung terus menghasilkan asam asetat.

\section{KESIMPULAN DAN SARAN}

\section{A. Kesimpulan}

Berdasarkan hasil penelitian dapat disimpulkan bahwa akar kayu bayur yang ditambahkan pada nira aren berfungsi sebagai pengawet tuak sehingga menyebabkan kadar alkohol 
hasil fermentasi nira aren bertahan lebih lama pada konsentrasi $4 \%$ selama 64 jam serta memperlambat fermentasi alkohol menjadi asam asetat.

\section{B. Saran}

Penelitian sebaiknya dilakukan di tempat pengambilan sampel nira agar penentuan kualitas nira dapat sesuai dengan yang diharapkan dan perlu penelitian lebih lanjut terhadap jenis akar kayu bayur yang baik digunakan dalam pengawetan tuak.

\section{DAFTAR PUSTAKA}

Firdaus dan Sinda. L. 2003. Peranan Kulit Kayu Buli Sonneratia sp Dalam Fermentasi Nira Aren Menjadi Minuman Beralkohol. Makassar: Universitas Hasanuddin.

Goutara dan S. Wijandi. 1980. Dasar-

Dasar Pengolahan Gula.

Bogor: Departemen Hasil Pertanian - IPB.

Hamzah, N dan Hasbullah. 1997. Evaluasi Mutu Gula Semut Yang Dibuat Dengan Menggunakan Beberapa Bahan Pengawet Alami. Prosiding Seminar Nasional teknologi
Pangan. Perhimpunan Ahli Teknologi Pangan.

Lutony, T.L. 1993. Tanaman Sumber Pemanis. P.T Penebar Swadaya, Jakarta.

Marzuki, A., Alfian, N., Nunuk, H.N., Harlim T. 2008. Pemeriksaan Farmakognostik Tumbuhan Pterospermum celebicum Miq. dan Penapisan Komponen Kimia Secara Kromatografi Lapis Tipis. Di dalam: Litaay M, Fachrudin, Soekendarsi E, Zulkifli A, editor. Prosiding Seminar Nasional Biologi XIX. Makassar; 9-10 Juli 2008. hal. 403-407.

Poedjiadi, A dan Titin, S. 2007. Dasar-Dasar Biokimia. Jakarta : UI-Press.

Putra, A.E dan Amran. H. 2009. Pembuatan Bioetanol Dari Nira Siwalan Secara Fermentasi Fase Cair Menggunakan Fermipan. Jurusan Teknik Kimia, universitas Diponegoro: Semarang.

Winarno, F.G., 1989. Kimia Pangan dan Gizi. Jakarta: Gramedia. 